\title{
Consumer attitude regarding products containing probiotics
}

\author{
Atitude do consumidor em relação a produtos contendo probióticos
}

\author{
Naiara Barbosa Carvalho ${ }^{\mathrm{I}^{*}}$ Thiago de Melo Teixeira da Costa ${ }^{\mathrm{II}}$ \\ Marco Aurélio Marques Ferreira ${ }^{I I}$ Andréa Alves Simiqueli \\ Valéria Paula Rodrigues Minim ${ }^{\mathrm{I}}$
}

\section{ABSTRACT}

This study sought to determine the attitude of consumers in the city of Viçosa-MG, Brazil in relation to products containing probiotics using a validated questionnaire. A total of 352 individuals responded to questionnaires which, in addition to the items of attitude, also assessed the health of consumers and acceptance and frequency of consumption of these products. Internal validation utilized the Cronbach coefficient to measure the reliability of the attitude scale. To analyze the profile of these consumers, descriptive statistics was utilized. The results indicated a low consumption of products containing probiotics by respondents. A reliable attitude scale was obtained $($ alpha $=0.70)$. In general, the attitude of respondents was positive however it was verified that there is a need to develop more explanatory labels, clearly stating the information allowed by Brazilian legislation, as well as strengthen campaigns to promote the benefits of consuming probiotic to the consumer.

Key words: probiotics, consumer, questionnaire, attitude, health benefits.

\section{RESUMO}

Neste trabalho, buscou-se verificar a atitude de consumidores da cidade de Viçosa-MG em relação a produtos contendo probióticos, por meio de um questionário validado para tal fim. Um total de 352 indivíduos respondeu aos questionários que, além dos itens de atitude, também avaliou questões de saúde dos consumidores, aceitação e frequência de consumo desses produtos. A validação interna valeu-se do coeficiente de Cronbach para medir a confiabilidade da escala de atitude. Para analisar o perfil desses consumidores, foi utilizada a estatística descritiva. Os resultados indicaram baixo consumo de produtos contendo probióticos pelos entrevistados. Foi obtida uma escala de atitude confível (alfa =0,70). De uma forma geral, a atitude dos entrevistados foi positiva, porém, verificou-se a necessidade de se desenvolver rótulos mais explicativos, expondo de forma clara as informações permitidas pela legislação brasileira, assim como reforçar as campanhas publicitárias que divulguem os benefícios do consumo de probióticos ao consumidor.

Palavras-chave: probióticos, consumidor, questionário, atitude, benefícios à saúde.

\section{INTRODUCTION}

Psychology considers that attitudes are composed of the three component model, including the following dimensions: the cognitive component, affective component, and conative component. The first consists of elaboration (thoughts) and the consequent knowledge acquired by means of a combination of experience with the available information. The cognitive component considers the beliefs of consumers on the product. The affective component refers to the emotions or feelings of the consumer with respect to a product or brand, generated from the affective experience of the situation. Finally, the conative component is related to the probability that the individual will behave in a specific way (SCHIFFMAN \& KANUK, 2009).

Thus, the acceptability of a product is determined not only by the sensory characteristics of the food, but the consumer relies on many other factors for judgment and to decide on selecting, consuming, enjoying and reusing the product. These other factors are those denominated as non-sensory characteristics and include the claims and features

\footnotetext{
'Departamento de Tecnologia de Alimentos, Universidade Federal de Viçosa (UFV), Av. Peter Henry Rolfs, s/n, 36570-900, Viçosa, MG, Brasil. E-mail: naiara.carvalho@ufv.br.*Autor para correspondência.

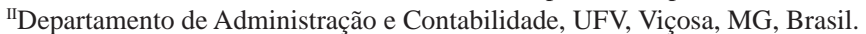


of the product, including the benefits and knowledge of functional ingredients and health benefits of the product (JAEGER, 2006).

In recent years a change in consumer behavior has been observed in which consumers are more concerned with health and welfare, indicating a growing interest in consuming "healthier" foods (VIDIGAL et al., 2011). Among the new and exciting concepts related to the foods whose health claims have been disclosed in recent years, probiotic foods are highlighted. Probiotics are living microorganisms which when administered in adequate amounts confer health benefits to the host (FAO/WHO, 2002).

In order for the consumers to develop or strengthen a positive attitude in relation to food probiotics it is necessary that they understand the benefits of this foods on human health. However, there is limited information regarding consumer knowledge on the benefits of probiotic foods. Investigating and understand the thoughts, beliefs, feelings and behavior of the consumer becomes extremely important for the food industry, since the main purpose is to obtain a positive attitude and consequent acceptance of this product by the consumer.

Based on the information provided, the objective of the present study was to verify the attitude of consumers in the city of Viçosa-MG, Brazil regarding products containing probiotics, as well as assess issues related to health of those interviewed and their consumption habits based on a validated questionnaire.

\section{MATERIALS AND METHODS}

Characterization of the research

A quantitative-descriptive study was performed (MALHOTRA, 2006) using a structured questionnaire with exploratory characteristics on the socio-demographic profile of the consumers, healthrelated disorders, consumption and attitude in respect to products containing probiotics. The questions were based on other studies of consumer products containing probiotics, and also on studies seeking to validate an attitude scale in relation to a specific object.

The questionnaires were administered at the Federal University of Viçosa - Viçosa/MG, Brazil, between the months of October and November 2011, with previous consent of the respondents. scale (Pre-test)

Elaboration of the attitude evaluation

According to the set of beliefs, knowledge and opinions obtained in the initial stage of the study, an attitude evaluation scale regarding products containing probiotics was constructed consisting of 20 items (phrases) on probiotics, in which half were negative and the other half positive, according to the methodology described by MUELLER (1986).

To assess consumer attitudes in relation to foods studied the seven-point Likert scale was used, where 7 was the greatest degree of concordance with the idea expressed by the item, and 1 represents a higher degree of discordance with the item (HAIR JR. et al., 2005).

The validity and power of segmentation of the formulated scale was tested according to the procedure suggested by MUELLER (1986). In this stage, the attitude scale was tested by a group of 50 individuals, including undergraduate and graduate students and faculty at the UFV, who had previously consumed or currently consume the products in question.

After obtaining the responses, the positive items of the scale received the values attributed to each category: in the category "strongly agree" a score 7 was computed until to the score 1 for the category "strongly disagree". The negative items were inversely computed.

Later these data were statistically analyzed by calculating the discrimination index of each item, which consisted of the Pearson correlation coefficient. The items presenting discrimination indices near or below zero were eliminated from the questionnaire.

\section{Final evaluation}

A final research questionnaire containing 14 items regarding probiotic foods was reapplied to a total of 352 individuals. These included undergraduate and graduate students and faculty of the UFV, selected according to the same criteria described in section "Elaboration of the attitude evaluation scale (Pre-test)”.

Pearson correlation coefficient was recalculated to discriminate the items and internal validation utilized the Cronbach coefficient to measure the reliability of the attitude scale (HAIR JR. et al., 2005; MUELLER, 1986).

The expression used to calculate the coefficient is given by Equation 1 in which:

$$
\alpha=\frac{N \bar{\rho}}{[1+\bar{\rho}(N-1)]}
$$

$\mathrm{N}=$ number of items; 
$\bar{\rho}=$ mean of the linear correlation coefficients (Pearson) between the items.

Characterization of the interviewed population and their consumption habits

Seeking to characterize the population interviewed and obtain information on consumption habits, questions were included regarding age, sex, education level, family income and health of the respondents, as well as the acceptance and frequency of consumption of probiotics. The degree of acceptance of the products was evaluated using a nine point hedonic scale ( 1 = extremely disliked, 9 = extremely liked) (MINIM, 2013).

The results were analyzed using a descriptive analysis. The analysis operating procedures were performed with the aid of the software SPSS $15.0^{\circledR}$.

\section{RESULTS AND DISCUSSION}

Sample profile

Of the 352 individuals who answered the final questionnaire, $44.60 \%$ were men and $55.40 \%$ women, and these are predominantly unmarried (92.33\%); the most common family income (20.50\%) was in the range of 1 to 3 minimum wages. Participants ranged from 16 to 72 years old, with a mean age of $22(\mathrm{SD}=5.21)$. The vast majority of respondents (96.40\%) had at least completed high school, and of these $44.03 \%$ had completed some college.

A total of $71.30 \%$ of the respondents said they did not possess any of the disorders included in the questionnaire. Of those that have at least one of the disorders in question, constipation (11.40\%) and gastritis $(10.50 \%)$ were cited as the most common, followed by high cholesterol (3.10\%), irritable bowel syndrome (2.80\%), lactose intolerance $(2.00 \%)$ and finally cardiovascular disease (1.10\%).

Because a segment of the population studies was composed of university students, it was found that the majority of participants in this study were young consumers with a high educational level.

Consumption and acceptance of products containing probiotics

Regarding the consumption of products containing probiotics, all stated they had consumed this type of product at least once. However, only $53.41 \%$ of respondents reported that they currently consume these products.

The data obtained indicated that yoghurt and fermented milk containing probiotics were the products best known and most consumed by participants of this study. Consumption of yoghurt and fermented milk by the population studied is quite high (86.00\%). Only $6.30 \%$ and $11.60 \%$ said they had never tried these products, respectively. This can be confirmed by a study conducted in 2003 and 2004, which indicated that consumption of yogurt has increased by $4 \%$ in Brazil (NEVES \& CÔNSOLI, 2006). However, the other products analyzed are virtually unknown and little consumed by this population, with high percentages selecting the option "never tried" $(78.40 \%$ for ice cream, $73.00 \%$ for cheese and $90.90 \%$ for capsules).

This result is consistent with published data, where according to SAAD (2006), dairy products such as fermented milk and yogurts are the main commercialized products containing probiotic cultures around the world.

When assessing exactly how much the respondents liked or disliked some of the products containing probiotics, it was found that yogurt and fermented milk products containing probiotics were the most accepted by respondents, with $85.70 \%$ and $74.40 \%$ respondents' scores fall between "6-slightly liked" to "9-extremely liked".

Yogurt containing probiotics is the product consumed most frequently by respondents, where $3.70 \%$ affirmed that they consume the product every day and $27.80 \%$ said they consume it at least once a week. This was followed by fermented milk containing probiotics which was the second most commonly consumed product among this population, where $3.10 \%$ reported consuming it every day and $18.80 \%$ said they consume it at least once a week. The other products showed high percentages for the never consumed option (82.10\% for the ice cream containing probiotics, $77.00 \%$ for cheese containing probiotics and $94.90 \%$ for capsules containing probiotics).

Thus, it was verified that the frequency of consuming yoghurt and/or fermented milk among participants is relatively low if considering the fact that the daily intake of these products is one of the major factors which guarantees that the beneficial effects attributed to probiotics are obtained. This was also observed by NEVES \& CÔNSOLI (2006) who similarly reported that a minority of $11 \%$ of respondents consumed yogurt daily.

Evaluation of consumer attitude in relation to products containing probiotics

In the preliminary test with the questionnaire, six of the 20 items making up the scale used to measure attitude towards products containing 
probiotics presented a negative or value close to zero for the discrimination index. Therefore, item 2 (Probiotic foods do not promote curing of diseases), item 4 (It is necessary to develop produces with improved flavor, texture, aroma and appearance), item 7 (Probiotic foods help to reduce cholesterol), item 8 (There is little variety of foods containing probiotics on the market), item 11 (Foods containing probiotics encountered on the market are generally expensive) and item 13 (Excessive consumption of probiotics may result in diarrhea, bloating and cramps) were eliminated from the questionnaire since they diminished the discrimination strength (or segmentation) and reliability of the scale, where the latter was evaluated by the Cronbach coefficient.

The attitude scale in relation to products containing probiotics, considering the remaining 14 items listed, presented a Cronbach coefficient equal to 0.70 (Tables 1 and 2). According to MULLER(1986) and HAIR JR. et al. (2005) a scale in which this coefficient is equal to or greater than 0.70 is a reliable instrument to measure attitudes on a related object. Therefore, the scale obtained in this study may be considered reliable, and moreover the discriminating power satisfactory, since the 14 items on the scale presented positive and significant discrimination indices (except for item 20) (Tables 1 and 2). According to BEHRENS \& DA SILVA (2004), the higher the discrimination index of an item, the greater its contribution to the attitude measurement scale. On the other hand, items with indices close to zero do not contribute to the power of the scale to segment the respondents.

It is observed that items 1, 3, 5 and 9 were those with mean scores ranging from 5.25 to 6.11 , reflecting greater frequency of responses between the categories of "somewhat agreed" and "highly agreed" on the Likert scale, indicating that they were the items with which the respondents most agreed with (Table 1).

According to the affirmations of items 5 and $9,88.60 \%$ and $80.50 \%$ of respondents agreed, respectively, at a level greater than or equal to "somewhat agreed" with the scientific definition of probiotics which states that they help relieve intestinal constipation, one of the most well-known benefits associated with the ingestion of probiotics by the interviewees. A smaller number of respondents, about $65.00 \%$, agreed with items 1 and 3 which state that "probiotics help to stabilize the intestinal flora after antibiotic use" and that these can provide therapeutic benefits for people suffering from irritable bowel syndrome. However, for these last two items approximately $30.00 \%$ of participants selecting the category "do not agree nor disagree”, revealing that a significant portion of respondents are unaware of the cited benefits of probiotics for human health. In general, these results suggest that this population is familiar with the meaning of the term "probiotics" and that the interviewees also know the importance of probiotics in promoting some of the many benefits related to human health.

For items 12, 15, 18 and 20 a high frequency of respondents assigned a score of 4 on the Likert scale expressing that they neither agreed nor disagreed with these questions. This demonstrates that a large number of respondents seemed unaware or not sure of appropriate quantities of probiotics that should be consumed daily and the health benefits provided to these items, especially items 12 "To assure a continuous effect probiotics should be taken daily and in adequate quantity (approximately $10^{8} \mathrm{CFU} \mathrm{ml} \mathrm{m}^{-1}$ )" and 20 "Probiotics promote lactose digestion in lactose intolerant individuals". However, it should be highlighted that item 20 presented a discrimination index close to zero, i.e., it revealed that most individuals have a common belief and this does not contribute to segment their opinions, as in the other items.

According to the Brazilian National Health Surveillance Agency (ANVISA, 2008), in order for a probiotic product to present a health claim on its label, it has been established that the minimum amount of viable culture should be between $10^{8}$ and $10^{9} \mathrm{CFU}$ (Colony Forming Units) per portion of the product.

A vital function of lactic acid bacteria (probiotics) in the intestinal microbiota is to produce the enzyme $\beta$ - D- galactosidade, assisting in breakdown of lactose in the intestine. This action is essential, particularly in the case of individuals with lactose intolerance who are unable to properly digest it, resulting in varying degrees of abdominal discomfort (LOURENS-HATTINGH \& VILJOEN, 2001). Several incidences have shown that consumption of appropriate amounts of adequate lactic bacteria strains are capable of alleviating the symptoms of lactose intolerance. Thus, it is possible to incorporate dairy products and the important nutrients which make up these products in the diet of individuals with lactose intolerance, who were previously required to refrain from the intake of these products.

Some of the items were negative with relation to products containing probiotics (Table 2). The lack of knowledge regarding the benefits conferred by the ingestion of probiotics in a reasonable proportion of the respondents can also be observed by means of responses obtained from items 6 "probiotics cause decreased absorption of essential minerals", 17 "probiotics affect production of vitamins leading 
Table 1 - Proportion of responses (\%) and average score of the POSITIVE ITEMS on the attitude scale in relation to products containing probiotics.

\begin{tabular}{|c|c|c|c|c|c|c|c|c|c|}
\hline Items & $\begin{array}{c}\text { Strongly } \\
\text { disagree } \\
\text { (\%) }\end{array}$ & $\begin{array}{c}\text { Moderate } \\
\text { disagree } \\
(\%)\end{array}$ & $\begin{array}{c}\text { Slightly } \\
\text { disagree } \\
\text { (\%) }\end{array}$ & $\begin{array}{l}\text { Neither } \\
\text { agree nor } \\
\text { disagree } \\
\text { (\%) }\end{array}$ & $\begin{array}{l}\text { Slightly } \\
\text { agree } \\
\text { (\%) }\end{array}$ & $\begin{array}{l}\text { Moderately } \\
\text { agree } \\
\text { (\%) }\end{array}$ & $\begin{array}{l}\text { Strongly } \\
\text { agree } \\
\text { (\%) }\end{array}$ & $\begin{array}{c}\text { Average } \\
\text { score } \pm \text { standard } \\
\text { deviation }\end{array}$ & $\begin{array}{c}\text { Discrimination } \\
\text { indices }\end{array}$ \\
\hline $\begin{array}{l}\text { 1. Probiotics aid } \\
\text { to establish the } \\
\text { intestinal flora } \\
\text { after the use of } \\
\text { antibiotics. }\end{array}$ & 3.4 & 2.6 & 2.0 & 26.7 & 14.2 & 21.9 & 29.3 & $5.28 \pm 1.56$ & $0.409 *$ \\
\hline $\begin{array}{l}\text { 3. For people } \\
\text { suffering from } \\
\text { irritable bowel } \\
\text { syndrome, the } \\
\text { administration of } \\
\text { probiotics may } \\
\text { result in } \\
\text { therapeutic } \\
\text { benefits. }\end{array}$ & 1.4 & 1.4 & 1.4 & 29.8 & 19.9 & 24.1 & 21.9 & $5.25+1.33$ & $0.494 *$ \\
\hline $\begin{array}{l}\text { 5. Probiotics are } \\
\text { live } \\
\text { microorganisms, } \\
\text { which in adequate } \\
\text { quantities provide } \\
\text { health benefits to } \\
\text { the consumer. }\end{array}$ & 0.3 & 0 & 0.3 & 10.8 & 13.6 & 26.1 & 48.9 & $6.11 \pm 1.07$ & $0.576^{*}$ \\
\hline $\begin{array}{l}\text { 9. Probiotics help } \\
\text { to relieve } \\
\text { intestinal } \\
\text { constipation. }\end{array}$ & 0.3 & 0.3 & 1.1 & 17.9 & 16.2 & 25.9 & 38.4 & $5.80+1.20$ & $0.529 *$ \\
\hline $\begin{array}{l}\text { 12. To assure a } \\
\text { continuous effect } \\
\text { probiotics should } \\
\text { be taken daily and } \\
\text { in adequate } \\
\text { quantity } \\
\text { (approximately } \\
10^{8} \mathrm{CFU} / \mathrm{ml} \text { ). }\end{array}$ & 1.1 & 0.6 & 1.7 & 56.0 & 11.1 & 13.6 & 15.9 & $4.80+1.26$ & $0.479 *$ \\
\hline $\begin{array}{l}\text { 14. Probiotic } \\
\text { foods on the table } \\
\text { represent health. }\end{array}$ & 3.7 & 3.7 & 7.1 & 31.5 & 23.3 & 19.0 & 11.6 & $4.71 \pm 1.45$ & $0.451^{*}$ \\
\hline $\begin{array}{l}\text { 15. Probiotics } \\
\text { promote } \\
\text { stimulation of the } \\
\text { immune system. }\end{array}$ & 2.3 & 3.1 & 9.4 & 49.1 & 17.0 & 10.2 & 8.8 & $4.41+1.28$ & $0.523 *$ \\
\hline $\begin{array}{l}\text { 18. Probiotics } \\
\text { stimulate the } \\
\text { proliferation of } \\
\text { beneficial bacteria } \\
\text { in the intestine, } \\
\text { rather than } \\
\text { proliferation of } \\
\text { bacteria } \\
\text { potentially } \\
\text { harmful to the } \\
\text { consumer. }\end{array}$ & 2.6 & 1.7 & 4.5 & 47.7 & 15.6 & 13.1 & 14.8 & $4.70+1.36$ & $0.499 *$ \\
\hline
\end{tabular}

Ciência Rural, v.44, n.7, jul, 2014. 
Table 2- Proportion of responses (\%) and average score of the NEGATIVE ITEMS of the attitude scale in relation to products containing probiotics.

\begin{tabular}{|c|c|c|c|c|c|c|c|c|c|}
\hline Items & $\begin{array}{c}\text { Strongly } \\
\text { disagree } \\
(\%)\end{array}$ & $\begin{array}{c}\text { Moderate } \\
\text { disagree } \\
(\%)\end{array}$ & $\begin{array}{c}\text { Slightly } \\
\text { disagree } \\
(\%)\end{array}$ & $\begin{array}{l}\text { Neither } \\
\text { agree nor } \\
\text { disagree } \\
\text { (\%) }\end{array}$ & $\begin{array}{l}\text { Slightly } \\
\text { agree } \\
\text { (\%) }\end{array}$ & $\begin{array}{l}\text { Moderately } \\
\text { agree } \\
\text { (\%) }\end{array}$ & $\begin{array}{l}\text { Strongly } \\
\text { agree } \\
(\%)\end{array}$ & $\begin{array}{l}\text { Average } \\
\text { score } \pm \text { standard } \\
\text { deviation }\end{array}$ & $\begin{array}{l}\text { Discrimination } \\
\text { indices }\end{array}$ \\
\hline $\begin{array}{l}\text { 6. Probiotics cause } \\
\text { decreased } \\
\text { absorption of } \\
\text { essential minerals. }\end{array}$ & 19.0 & 9.7 & 8.8 & 55.1 & 5.1 & 1.7 & 0.6 & $3.25 \pm 1.34$ & $0.581^{*}$ \\
\hline $\begin{array}{l}\text { 10. Labels on } \\
\text { products } \\
\text { containing } \\
\text { probiotics do not } \\
\text { provide clear } \\
\text { information on } \\
\text { their benefits. }\end{array}$ & 3.4 & 7.4 & 8.8 & 21.3 & 19.3 & 21.0 & 18.8 & $4.84 \pm 1.65$ & $0.192 *$ \\
\hline $\begin{array}{l}\text { 16. Products } \\
\text { containing } \\
\text { probiotics are not } \\
\text { easily digested. }\end{array}$ & 28.4 & 16.8 & 20.2 & 28.4 & 2.6 & 2.3 & 1.4 & $2.72 \pm 1.43$ & $0.520 *$ \\
\hline $\begin{array}{l}\text { 17. Probiotics } \\
\text { affect production } \\
\text { of vitamins } \\
\text { leading to their } \\
\text { reduction. }\end{array}$ & 17.6 & 14.2 & 10.2 & 55.4 & 1.7 & 0.3 & 0.6 & $3.13+1.25$ & $0.526 *$ \\
\hline $\begin{array}{l}\text { 19. Daily } \\
\text { consumption of } \\
\text { probiotics can } \\
\text { trigger a } \\
\text { damaging } \\
\text { inflammatory } \\
\text { response. }\end{array}$ & 16.8 & 11.1 & 12.5 & 53.4 & 3.7 & 0.9 & 1.7 & $3.26 \pm 1.32$ & $0.582 *$ \\
\hline
\end{tabular}

*Significant discrimination indices $(\mathrm{P}<0.10)$.

to their reduction" and 19 "daily consumption of probiotics can trigger a damaging inflammatory response", all of which received a score of 4 by $53.00 \%$ and $55.00 \%$ of respondents, where these statements are false.

The action of microorganisms during the manufacture of products containing probiotic cultures or in the digestive tract favorably influences the quantity, bioavailability and digestibility of some nutrients. Fermentation of dairy products by lactic bacteria can increase the concentration of determined nutrients, such as vitamins B. Lactic bacteria are characterized by the release of various enzymes in the intestinal lumen. These enzymes have synergistic effects on digestion, relieving symptoms of nutrient absorption deficiency (KOPP- HOOLIHAN, 2001).
According to SAAD (2006), the effects of probiotics on immune response have been extensively studied. It is believed that these effects are mediated by the activation of macrophages, by an increase in cytokine levels, by an increase in natural killer cell activity and/or levels of immunoglobulins. According to this author, the fact that these positive effects of probiotics on the immune system occur without triggering a damaging inflammatory response deserves to be highlighted.

With respect to item $16,65.40 \%$ of the respondents disagree that products containing probiotics are difficult to digest, information which is in fact false (Table 2). Regarding probiotics, controlled clinical studies with lactobacilli and bifidobacteria showed no deleterious effects caused by these microorganisms (LEE et al., 1999). 
With respect to item $14,53.90 \%$ of the respondents agreed that foods containing probiotics promote good health and $31.00 \%$ neither agree nor disagree with this proposition. This fact may be closely related to the evidence that $59.10 \%$ of these individuals agree that the labels of these products do not provide clear information about their benefits (Item 10), and therefore a large portion of the study participants did not have clear knowledge about the benefits conferred by these products and that how they promote good health.

ANTUNES et al. (2007) affirmed that according to Brazilian law, products that have probiotic cultures in their composition must declare the probiotic microorganism species and the amount of probiotic colony forming units contained in the daily portion the product should also be declared on the label outside the nutritional information table. Brazilian legislation, unlike that of other countries, prohibits reference to the claims of disease prevention and treatment on food labels since many factors are involved in these processes. Only claims that the food promotes health are allowed. This may be a factor that hinders providing information regarding scientifically proven benefits to the final consumer, explaining the advantages of consuming such products and also for marketing strategies which seek to promote functional foods such as probiotics.

In the study performed by SILVA et al., (2008), evaluation of the label of products containing probiotics that are marketed in Brazil was performed to determine if they were in line with legislation requirements. Faults were detected in the labeling of various products, indicating the continuing need for vigilance to ensure that product labels are appropriate and consumers obtain the correct information.

\section{CONCLUSION}

Regarding the construction of the attitude scale, the objective of this study was to provide a reliable tool for measuring consumer attitudes for studies on products containing probiotics, which are being increasingly consumed by the Brazilian population.

Few respondents reported they properly consume, on a daily basis, the products analyzed. So, labels must be developed to provide more information to the consumers in general, with a greater disclosure that they contain probiotic cultures. Strategies and investments in marketing campaigns should also be utilized in order to provide adequate knowledge on the numerous benefits related to daily consumption of these products.
Thus, it is expected that consumers become aware, feel motivated and have a more positive attitude regarding such products, stimulating purchase and consumption of these products.

\section{ETHICS COMMITTEE}

This project was analyzed and approved by the Scientific Committee of the Postgraduate Department of Food Technology - Federal University of Viçosa, process n. 60201262279/2011, obeying, as outlined, the necessary requirements for its publication.

\section{ACKNOWLEDGEMENS}

The authors are grateful to Conselho Nacional de Desenvolvimento Científico e Tecnológico (CNPq), Coordenação de Aperfeiçoamento de Pessoal de Nível Superior (CAPES) and Fundação de Amparo à Pesquisa do estado de Minas Gerais (FAMEPIG) for the financial support.

\section{REFERENCES}

ANTUNES, A.E.C. et al. Desenvolvimento de buttermilk probiótico. Ciência e Tecnologia de Alimentos, v.27, n.1, p.8390, 2007. Available from: <http://dx.doi.org/10.1590/S010120612007000100015>. Accessed: Nov 29, 2011. doi: 10.1590/ S0101-20612007000100015.

ANVISA (AGÊNCIA NACIONAL DE VIGILÂNCIA SANITÁRIA). Alimentos com alegações de propriedades funcionais e ou de saúde, novos alimentos/ingredientes, substâncias bioativas e probióticos: IX lista de alegações de propriedade funcional aprovada, atualizado em julho/2008. Available from: <http://www.anvisa.gov.br/alimentos/comissoes/ tecno_lista_alega.htm>. Accessed: Nov 13, 2011.

BEHRENS, J.H.; DA SILVA, M.A.A.P. Atitude do consumidor em relação à soja e produtos derivados. Ciência e Tecnologia de Alimentos, v.24, n.3, p.431-439, 2004. Available from: <http:// dx.doi.org/10.1590/S0101-20612004000300023>. Accessed: Nov 17, 2011. doi: 10.1590/S0101-20612004000300023.

FOOD AND AGRICULTURE ORGANIZATION OF THE UNITED NATIONS, WORLD HEALTH ORGANIZATION. Guidelines for the evaluation of probiotics in food. London, Ontario, Canada: Joint FAO/WHO, 2002. 11p.

HAIR JR, J.F. et al. Fundamentos de métodos de pesquisa em administração. Porto Alegre: Bookman, 2005. 471p.

JAEGER, S.R. Non-sensory factors in sensory science research. Food Quality and Preference, v.17, n.1-2, p.132144, 2006. Available from: <http://dx.doi.org/10.1016/j. foodqual.2005.03.004>. Accessed: Nov 9, 2011. doi: 10.1016/j. foodqual.2005.03.004.

KOPP-HOOLIHAN, L. Prophylactic and therapeutic uses of probiotics: a review. Journal American Dietetic Association, v.101, p.229-241, 2001. Available from: <http://dx.doi. org/10.1016/S0002-8223(01)00060-8>. Accessed: Nov 17, 2011. doi: 10.1016/S0002-8223(01)00060-8.

LEE, Y.K. et al. Handbook of probiotics. New York: Wiley, 1999. 211p. 
LOURENS-HATTINGH, A.; VILJOEN, B.C. Yogurt as probiotic carrier food. International Dairy Journal, v.11, n.1-2, p.117, 2001. Available from: <http://dx.doi.org/10.1016/S09586946(01)00036-X>. Accessed: Nov 28, 2011. doi: 10.1016/S09586946(01)00036-X.

MALHOTRA, N.K. Pesquisa de marketing: uma orientação aplicada. 4.ed. Porto Alegre: Bookman, 2006. 720p.

MINIM, V.P.R. Análise sensorial: estudos com consumidores. 3.ed. Viçosa: UFV, 2013. 332p.

MUELLER, D.J. Measuring social attitudes: a handbook for researchers and practioners. New York: Teachers College, 1986. 123p.

NEVES, M.F.; CÔNSOLI, M.A. Estratégias para o leite no brasil. Oakes: Atlas, 2006. 304p.

SAAD, S.M.I. Probióticos e prebióticos: o estado da arte. Revista Brasileira de Ciência Farmacêuticas, v.42, n.1, p.1-16, 2006.
Available from: <http://www.scielo.br/pdf/rbcf/v42n1/29855. pdf $>$. Accessed: Nov 16, 2011.

SCHIFFMAN, L.G.; KANUK, L.L. Consumer behavior. New Jersey: Prentice Hall, 2009. 600 p.

SILVA, E.G.B. et al. Evaluation of the labels of brazilian probiotic and prebiotic dairy foods. In: SIMPÓSIO INTERNACIONAL: PREBIÓTICOS E PROBIÓTICOS EM PRODUTOS LÁCTEOS, 2008, Campinas, SP. Anais... Campinas: ITAL, 2008. 1 f. 1 CD-ROM.

VIDIGAL, M.C.T.R. et al. Effect of a health claim on consumer acceptance of exotic Brazilian fruit juices: Açaí (Euterpeoleracea Mart.), Camu-camu (Myrciariadubia), Cajá (Spondiaslutea L.) and Umbu (Spondias tuberosa Arruda). Food Research International, v.44, n.7, p.1988-1996, 2011. Available from: $<$ http://dx.doi.org/10.1016/j.foodres.2010.11.028>. Accesse Nov 26, 2011. doi: 10.1016/j.foodres.2010.11.028. 